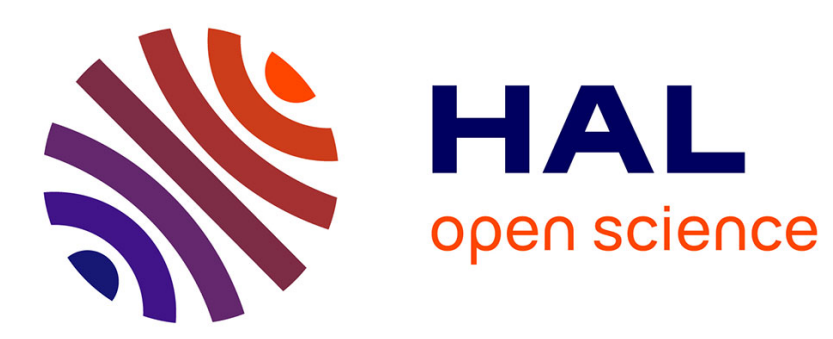

\title{
Plant biodiversity enhances bees and other insect pollinators in agroecosystems. A review
}

\author{
Clara Nicholls, Miguel Altieri
}

\section{To cite this version:}

Clara Nicholls, Miguel Altieri. Plant biodiversity enhances bees and other insect pollinators in agroecosystems. A review. Agronomy for Sustainable Development, 2013, 33 (2), pp.257-274. 10.1007/s13593-012-0092-y . hal-01201380

\section{HAL Id: hal-01201380 \\ https://hal.science/hal-01201380}

Submitted on 17 Sep 2015

HAL is a multi-disciplinary open access archive for the deposit and dissemination of scientific research documents, whether they are published or not. The documents may come from teaching and research institutions in France or abroad, or from public or private research centers.
L'archive ouverte pluridisciplinaire HAL, est destinée au dépôt et à la diffusion de documents scientifiques de niveau recherche, publiés ou non, émanant des établissements d'enseignement et de recherche français ou étrangers, des laboratoires publics ou privés. 


\title{
Plant biodiversity enhances bees and other insect pollinators in agroecosystems. A review
}

\author{
Clara I. Nicholls • Miguel A. Altieri
}

Accepted: 25 March 2012 / Published online: 14 June 2012

(C) INRA and Springer-Verlag, France 2012

\begin{abstract}
Thirty-five percent of global production from crops including at least 800 cultivated plants depend on animal pollination. The transformation of agriculture in the past half-century has triggered a decline in bees and other insect pollinators. In North America, losses of bee colonies have accelerated since 2004, leaving the continent with fewer managed pollinators than at any time in the past 50 years. A number of factors linked to industrial modes of agriculture affect bee colonies and other pollinators around the world, ranging from habitat degradation due to monocultures with consequent declines in flowering plants and the use of damaging insecticides. Incentives should be offered to farmers to restore pollinator-friendly habitats, including flower provisioning within or around crop fields and elimination of use of insecticides by adopting agroecological production methods. Conventional farmers should be extremely cautious in the choice, timing, and application of insecticides and other chemicals. Here, we review the literature providing mounting evidence that the restoration of plant biodiversity within and around crop fields can improve habitat for domestic and wild bees as well as other insects and thus enhance pollination services in agroecosystems. Main findings are the following: (1) certain weed species within crop fields that provide food resources and refuge should be maintained at tolerable levels within crop fields to aid in the survival of viable populations of pollinators. (2) Careful manipulation strategies need to be defined in order to avoid weed competition with crops and interference with certain cultural practices. Economic thresholds of weed populations, as well as factors affecting cropweed balance within a crop season, need to be defined for
\end{abstract}

C. I. Nicholls $\cdot$ M. A. Altieri $(\bowtie)$

University of California,

Berkeley, CA, USA

e-mail: agroeco3@berkeley.edu specific cropping systems. (3) More research is warranted to advance knowledge on identifying beneficial weed species and ways to sponsor them to attract pollinators while not reducing yields through interference. (4) In areas of intensive farming, field margins, field edges and paths, headlands, fence-lines, rights of way, and nearby uncultivated patches of land are important refuges for many pollinators. (5) Maintenance and restoration of hedgerows and other vegetation features at field borders is therefore essential for harboring pollinators. (6) Appropriate management of non-cropped areas to encourage wild pollinators may prove to be a costeffective means of maximizing crop yield.

Keywords Pollinators $\cdot$ Habitat management $\cdot$ Weed manipulation $\cdot$ Hedgerows $\cdot$ Agroecosystems

Contents

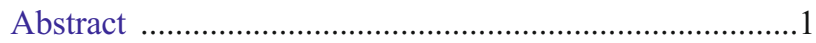

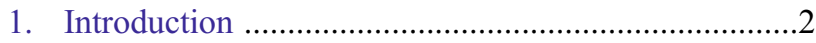

2. Ecological interactions among crops, weeds and beneficial insects ...................................................... 6

3. Effects of agricultural practices on wild pollinators .....2

4. Farming practices ........................................................

5. Agronomic strategies to encourage weeds beneficial to pollinator ....

6. Maintaining tolerable levels of weed densities in the

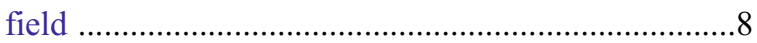

7. Practical tips for encouraging pollinator friendly

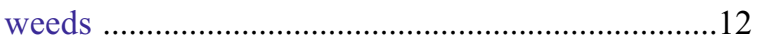

8. Costs-benefits to crop productivity of promoting pollinator friendly weeds ........................................13

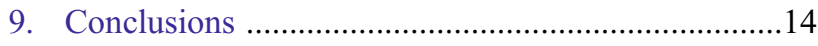

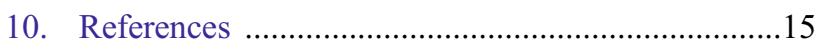
(1) (1) 


\section{Introduction}

Agriculture poses many threats to insect pollinators such as changes in land use, loss and fragmentation of habitat, introduction of exotic organisms, modern agricultural practices, and pesticide use. Removal of weeds that provide forage for pollinators is a major factor in the decline of native pollinators in agroecosystems (Richards 2001; Steffan-Dewenter et al. 2005). A pioneering study by Benedek (1972) was among the first to report a dramatic change in the structure of Lucerne wild bee populations between the 1950s and 1960s linked with a rapid increase in field size and an increased use of mechanical weed control along the field's road sides associated with enhanced use of herbicides within crop fields.

Because of the ecological link between plant resources and insect biology, entomologists have long noted the positive role of weeds in enhancing beneficial insect survivorship in crop ecosystems (van Emden 1963, 1965). For more than 45 years, biological control practitioners have been aware that the manipulation of specific weed species and/ or the use of a particular weed control practice in a cropping system can affect the ecology of insect pests and associated natural enemies (Altieri et al. 1977; Altieri and Whitcomb 1979a; Thresh 1981; William 1981; Norris 1982). These studies helped establish the foundations for strategies to manipulate natural enemies via weed management (Altieri et al. 1977; Altieri and Whitcomb 1979a).

Despite the fact that pollinators share similar habitat and resource requirements provided by flowers as arthropod natural enemies, very few studies have explored the potential to utilize weed vegetation management as a tool to enhance pollinator diversity and abundance in agroecosystems. In an attempt to fill this gap in knowledge, this paper explores the multiple interactions among crops, weeds, and insect pollinators and, in particular, how weed ecology and management can affect the dynamics of insect pollinators as well as natural enemies and hence benefit both crop health and yields. A challenging task addressed in the paper is to define a habitat management strategy in which weed manipulation plays a key role in enhancing key pollinator and natural enemy species, thus simultaneously achieving pollination and biological control services.

It is herein posited that the "pollination crisis" manifested as declines of honeybees and native bees may be ameliorated by changes in agricultural practices that restore habitats for beneficial arthropods (pollinators and natural enemies) by properly managing weeds within and around cropping systems. Investment in the restoration and management of a diversity of pollinators and their habitats in croplands are of key importance for the stability of the yield of food crops, especially when considering that $35 \%$ of global production comes from crops (at least 800 cultivated plants) that depend on animal pollination (Allen-Wardell et al. 1998; Richards 2001; Klein et al. 2007 and Gallai et al. 2009).

\section{Effects of agricultural practices on wild pollinators}

Natural pollination systems are characterized by broad flower types exhibiting particular reward patterns as to attract particular kinds of pollinators. Different kinds of flowers of varying phenologies attract different visitors cementing the mutualisms and by implication tending to make flowers increasingly specialist and visitors more and more selective (Willmer 2011). Such co-evolutionary processes have been interrupted in modern agroecosystems dominated by a uniformity of flowers with similar sizes, shapes, and colors. These flowers usually bloom massively in synchronous periods only lasting a few weeks so that peak numbers of pollinators are needed in a short time. The floral diversity formerly provided by hedges, weed patches, field margins, and uncultivated land that could sustain abundant and diverse pollinator assemblages to cover such periods have been eliminated in intensive agricultural systems.

Several features associated with modern agriculture make farms poor habitat for wild bees and other pollinators, and many agricultural practices impact directly or indirectly pollinator populations (Kremen et al. 2002). Agricultural intensification has led to a more homogeneous landscape characterized by large weed-free fields and fewer non cultivated habitats. Habitat loss and degradation, e.g., loss of complex landscape structures between farmland and adjacent ecosystems, as well as the increased use of agrochemicals, have been linked to the reduction in beneficial arthropod species richness in agricultural landscapes (Kevan 1999)

\subsection{Vegetational simplification of agroecosystems}

Crop monocultures sacrifice floral diversity and, consequently, diversity of pollinating insects, over large areas. A large body of research shows that cultivated fields surrounded by simple habitats (i.e., other monocultures) have significantly fewer bees than crops surrounded by uncultivated land, and the number of bumblebees on crops increases with proximity to natural habitats (Ockinger and Smith 2007). The conversion of land to agriculture results in a net loss of wild vegetation to support pollinators reducing nesting sites and less-varied microhabitats for egg laying and larval development. In this regard, the loss of hedgerow habitats, which provide floral resources and nesting sites for wild bees at the margins of cultivated fields is an undesirable trend associated with industrial agriculture (New 2005).

Several entomologists and ecologists have suggested that isolation from critical floral and nesting resources present in wild lands is likely to be the key factor explaining the decline in abundance and diversity of native bees in crop fields and attendant loss of pollination services. Research in California showed that both native bee diversity and abundance are significantly related to the proportional area of 
wild habitat surrounding the farm (Kremen et al. 2004). These researchers, documented the individual species and aggregate community contributions of native bees to crop pollination on farms that varied both in their proximity to natural habitat and management type (organic versus conventional). On organic farms near natural habitat, they found that native bee communities could provide full pollination services even for a crop with heavy pollination requirements (e.g., watermelon, Citrullus lanatus), without the intervention of managed honeybees.

Conventional farms isolated from wild vegetation experienced greatly reduced diversity and abundance of native bees, resulting in insufficient pollination services from native bees alone.

\subsection{The influence of adjacent habitats}

Semi-natural land is thought to be important for bumblebees in agricultural landscapes (Fig. 1). Canadian canola fields with semi-natural pastureland within $800 \mathrm{~m}$ of field edges had more bumblebees than fields that were almost completely surrounded by tilled cropland (Morandin et al. 2007). Similarly, bee abundance was greatest in canola fields that had more uncultivated land within $750 \mathrm{~m}$ of field edges, and seed set was greater in fields with higher bee abundance. A cost-benefit model that estimates profit in canola agroecosystems with different proportions of uncultivated land is presented. Yield and profit could be maximized with $30 \%$ of land uncultivated within $750 \mathrm{~m}$ of field edges (Morandin and Winston 2006). The economic and yield implications of maintaining uncultivated land to enhance pollinator services is discussed in the "Costs-benefits to crop productivity of promoting pollinator friendly weeds" section of this paper.

A study of the pollinator entomofauna associated with orchards and surrounding areas in the Okanagan Valley of British Columbia reveals the key role of flowering weedy

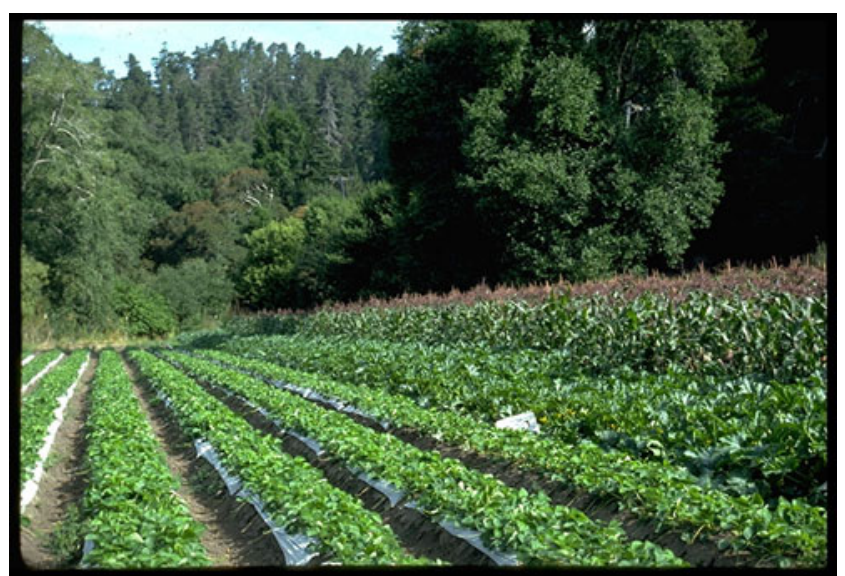

Fig. 1 Small diversified organic farm surrounded by native vegetation vegetation adjacent to crop fields in harboring pollinators. The highest capture rates of wild bees came from flowers in uncultivated areas near orchards (ranged from approximately $10.4-17.5$ bees per hour). These rates were much higher than those recorded within orchards, i.e., at $2.5-5.8$ bees per hour. The lowest values were obtained in orchards far from uncultivated areas (Scott-Dupree and Winston 1987).

Similarly, in the Lower Fraser Valley of British Columbia, researchers (Mackenzie and Winston 1984) found that both abundance and diversity of pollinators were lower on the crop plants (blueberry, raspberry, etc.) than on the surrounding native vegetation (Shannon-Wiener indices in the natural areas ranged from 1.18 to 0.61 versus 0.75 to 0.29 on the crops).

In Finland, bumblebee species richness and total density were higher in patches of farmland where field margins (1.5-2.5 $\mathrm{m}$ in width) had more dicotyledonous flowers rather than being grassy. Abundance and flowering phenology of a limited number of flower species during the bumblebee-breeding season were the most important factors explaining bumblebee visits in field margins. The most important flower species was zigzag clover (Trifolium medium). The width of field margins was significantly related to the total density of bumblebees and cuckoo bumblebees (Backman and Tiainen 2002).

Results from a study with sunflowers in South Africa show that, if farmers allow ruderal plants to co-exist with pollinator-dependent crops, diverse flower visitors are able to persist in isolated areas of cultivation areas, benefiting production. Such benefits maximize the positive effects of the remaining patches of natural habitat. As ruderal plants did not compete with sunflower for soil resources or reduce plantation area, this practice would bring no added costs to farmers, even reducing herbicide application costs (Lagerlof et al. 1992). A more recent study conducted in South African sunflower plots where researchers combined pollinator exclusion experiments with analysis of honeybee behavior and flower-visitation webs, found that the presence of weeds allowed pollinators to persist within sunflower fields, maximizing the benefits of the remaining patches of natural habitat to productivity of this large-scale crop (Carvalheiro et al. 2011). Weed diversity increased flower visitor diversity, hence ameliorating the measured negative effects of isolation from natural habitat. Although honeybees were the most abundant visitors, diversity of flower visitors enhanced honeybee movement, being the main factor influencing productivity. When analyzing variation in productivity throughout the farms, authors found that seed mass declined significantly with distance to natural habitat and increased significantly with species richness of ruderal flowers. The positive effect of ruderal flower diversity was significant at any distance from natural habitat and was independent of ruderal cover. 


\subsection{Field size}

Another negative trend affecting pollinators is the ongoing increase in farm size with farms specialized in either crop or animal production. In southeastern Sweden, researchers found more than twice as many butterflies and five times more bumblebees in small $(<52$ ha) than in large farms (>135 ha). Larger fields usually characterized by monocultures, use practices that affect farm landscape diversity, reducing non-cultivated habitats which provide floral resources and nesting sites for wild bees at the margins of cultivated fields. Farms with large field sizes necessarily have a low proportion of hedgerows or other field margins, and since these are the places that provide nest sites and floral resources for wild pollinators when crops are not flowering, then farms with large fields will have relatively few pollinators, regardless of the pesticide regime adopted (Belfrage et al. 2005).

If field sizes are very large, then there may simply not be enough wild bees to go around. Yield of crops may be limited if there are insufficient bees to visit all of the flowers. For example, in fields exceeding 12 ha in size, the yield of field beans was reduced through inadequate pollination by long tongued bumblebees.

Similarly, if field sizes exceeded 5 ha, yield of red clover in New Zealand declined through a shortage of bumblebees. At present, the area of land in the European Union and USA under entomophilous crops is increasing, and some researchers have predicted that we will soon be facing a serious shortage of both wild and managed bees (Richards 2001; Aizen et al. 2008).

Farm size is also associated with different types of farming practices that may or may not encourage wild pollinators. For example, organic farming is mainly adopted by small farmers, and organic farms have been shown to increase biodiversity (Hole et al. 2004). But, organic farms differ from conventional farms in more ways than use of agrochemicals. Usually, organic farmers cultivate many different crops enhancing farm diversity, and at times, many small fields are surrounded by edges enhancing landscape diversity. All these features help conserve pollinators (Feber et al. 1997), as was found in Sweden that small organic farms had greater populations of bumblebees than large organic and conventional farms (Belfrage et al. 2005).

\section{Farming practices}

\subsection{Tillage}

The introduction of new tillage practices (reduced, minimum, or non-tillage) commonly causes changes in the composition and abundance of weed species present in cropping systems. In arable crops such as soybean and maize weed, population shifts were observed when conventional tillage systems were changed to non-tillage (Ball and Miller 1990). Annual grass populations usually increase in non-tillage systems (Wrucke and Arnold 1985) whereas decreased populations of annual dicotyledonous weeds have been associated with non-tillage, which in turn may reduce floral resources for pollinators. On the other hand, tillage practices that create special soil cover conditions influence pollinator abundance as shown in a survey of 25 squash and pumpkin farms in West Virginia and Maryland. Researchers found that squash bee density was three times higher in no-tillage farms than in tilled farms. Many small farmers that leave residues on soil or practice mulching may be inadvertently encouraging wild bees (Shuler et al. 2005). Extensive tillage practices that inhibit or destroy nests should be avoided. Often times, diverse farms with a variety of landscape features including patches of bare soil, piles, or hedgerows of stone and clump-forming grasses can provide ample nest habitat for wild bees (Steffan-Dewenter 2002).

\subsection{Rotations}

Crop rotations affect weed seed-banks because weed control measures change with successive crops thus influencing weed species composition abundance. In the few studies, where rotation effects on weeds have been examined without herbicides as a confounding factor, rotation by itself led to reduced weed populations, especially where a small grain was included in the rotation. However, where crops are rotated, weed communities are more diverse than where crops are grown in monoculture, which again creates more favorable habitat and food conditions for pollinators (Ball 1992). The operational principle at work here is density versus diversity, as rotations tend to reduce weed density but enhance weed species diversity.

\subsection{Insecticide-induced pollinator declines}

The use of pesticides in agriculture is well documented as causing pollinator declines, especially where spraying time coincides with flowering time. Insecticides pose a major threat to pollinators, and pesticide-induced declines in bee abundance are yearly reported in many countries of the world. Deliberate misuse of pesticides despite label warnings and recommendations has caused major pollinator kills (Johansen 1977). The use of diazinon to control aphids in alfalfa fields resulted in massive declines of pollinating alkali bees, which took several years to show recovery (Johansen and Mayer 1990). Poisoning of honeybees (on which most attention has been focused) can result in direct mortality and displacement of queens. Less understood is the problem of sub-lethal effects, which reduce longevity 
and adversely affect foraging, memory, and navigational abilities of some bees. Pesticides have been detected in contaminated honey or pollen, indicating that foraging honeybees can contaminate the hive with pesticides or other pollutants (Buchmann and Nabhan 1996). Bees are particularly sensitive to many organophosphate insecticides such as fenitothrion and malathion (Johansen and Mayer 1990).

Wild pollinators are often more susceptible to pesticides than are domestic honeybees, and wild pollinators may be eliminated completely from a crop environment and its surrounds or may take several years to recover to normal pre-treatment levels (Johansen 1977). While farmers may be aware that pesticides should not be applied on pollinator-dependent crops at time of flowering, pesticides applied at other periods on crops will occur on weed flowers, and pollinators, which visit these, may be heavily impacted. Pollinators living on field margins can be affected by either intentional or accidental pesticide use, and effects may be lethal or sub-lethal. Micro-scale effects of pesticide applications are very variable and are likely to vary according to type of pesticide use, vulnerability of pollinator species, vegetation type, and time of application. A recent butterfly survey conducted in The Netherlands emphasized the importance of timing of pesticide use, because most butterflies are likely to be affected mainly during their caterpillar stage on plants. Unfortunately, in that country, $65 \%$ of agricultural pesticides are used from May to August, when caterpillars of many butterfly species are most abundant (New 2005).

Application of pesticides to control non-agricultural pests in non-agricultural ecosystems can also affect pollination abundance and activity in nearby crops. From 1969 until 1978, spruce budworm in Eastern Canada was controlled by aerial spraying of fenitrothion, an organophosphate that is highly toxic to bees. Commercial blueberry production in the region largely depended on pollination by as many as 70 species of native insects including bumblebees, andrenid, and halictid bees, which declined, in blueberry fields near sprayed forests. Blueberry crops failed in 1970 and subsequent years until the pesticide was replaced by other less toxic compounds. It took up to 8 years to recover normal population levels after cessation of aerial sprays of fenitrothion against spruce budworm in nearby coniferous forests (Kevan and Plowright 1989).

Mosquito control programs have been associated with major losses of honeybees in Canada and the USA. In Manitoba, efforts to combat outbreaks of western equine encephalitis by controlling its mosquito vectors resulted in damage to colonies of honeybees totaling $\$ 90,000$ in 1981 and \$850,000 in 1983 (Dixon and Fingler 1982, 1984).

\subsection{Weed removal}

Herbicide use affects pollinators by reducing the availability of nectar plants. It is well known that herbicide spraying and mechanical weed control in alfalfa fields reduce nectar sources for wild bees (Stephen 1955). The magnitude of the effect for each species is related to the length of its seasonal flight period. Many bees have a flight period that extends beyond the availability of alfalfa flowers. Some of these bee populations show massive declines due to the lack of suitable nesting sites and alternative food plants (Benedek 1996). This situation is also common in other agroecosystems where flowering weeds are eliminated especially in periods where the main crops are not flowering.

By destroying larval food sources and safe sites, herbicides can also severely affect pollinator populations (Kevan et al. 1997). Moreby and Southway (1999) and Dover et al. (1990) found that wheat field headlands untreated with herbicide contained much higher populations of several groups of insects, including Coleoptera and Lepidoptera, than did those which had been treated. A major use of herbicides by some farmers is to control perennial weeds around crop edges. This is often accompanied by increase of annual grass weed species, so that a species (and-flower)-impoverished community is established replacing a more diverse assemblage of dicotyledonous weeds thus substantially reducing flower resources for beneficial invertebrates.

In the case of biocontrol agents, the failure to attain high populations of predators and parasitoids in weed free crops is aggravated due to the lack of floral resources. The high incidence of natural biocontrol agents of pestiferous insects in lowinput agricultural systems have been ascribed to the availability of floral resources. Successful establishment of several parasitoids has depended on the presence of weeds that provided nectar for the adult female wasps (Altieri and Nicholls 2004).

In the last 30 years, research has shown that outbreaks of certain types of crop pests are less likely to occur in weeddiversified crop systems than in weed-free fields, mainly due to increased mortality imposed by natural enemies (Pimentel 1961; Adams and Drew 1965; Dempster 1969; Flaherty 1969; Smith 1969; Root 1973; Altieri et al. 1977). Crop fields with a dense weed cover and high diversity usually have more predaceous and parasitic arthropods than do weed-free fields, although, if weeds are left uncontrolled, crop yields can be significantly reduced (Perrin 1975; Speight and Lawton 1976). Relevant examples of cropping systems, in which the presence of tolerable levels of specific weeds has enhanced the biological control of particular pests, are reported by Altieri and Letourneau (1982). A literature survey by Baliddawa (1985) showed that population densities of 27 insect species were reduced in weedy crops compared with weed-free crops, mainly due to enhanced natural enemy populations.

3.5 Effects of genetically modified crops on pollinator impoverishment

The farm scale evaluation carried out during 2005 in the UK found that conventional crops of beet and spring rape harbored 
more pollinators such as butterflies and bees because there were more weeds to provide food and shelter, as compared with biotech crops that are genetically engineered to tolerate herbicide applications (Hawes et al. 2003). Many crops have now been modified with resistance to herbicides such as glyphosate, imidazolinone, sulfonylurea, and glufosinates. Modification with herbicide resistance is most likely to cause environmental damage to pollinator systems as a result of the ease by which entomophilous weeds non-resistant to the herbicides will be removed from the agricultural landscape (O'Callaghan et al. 2005).

Insect resistance, based on Bacillus thuringiensis endotoxins, is the second most widely used trait (after herbicide resistance) in commercial genetically modified (GM) crops. Other modifications for insect resistance, such as proteinase inhibitors and lectins, are also being used in many experimental crops. Neither $B$. thuringiensis cotton nor $B$. thuringiensis maize requires bees for pollination, but cotton nectar is attractive to them and produces a useful honey. Maize pollen may be collected when other pollen sources are scarce (Groot and Dicke 2002). Pre-release honeybee biosafety tests have been conducted for each $B$. thuringiensis crop registered in the USA, including Cry9C maize and Cry3A potatoes. Each test involved feeding bee larvae and sometimes adults with purified Cry proteins in sucrose solutions at concentrations that greatly exceeded those recorded from the pollen or nectar of the GM plants in question. In each case, no effects were observed. The rationale for requiring larval and not adult bee tests is questionable, because adult bees ingest considerable quantities of pollen in their first few days post-emergence. Larvae, particularly later instars, also consume pollen along with jelly secreted by nurse adult bees, but only recently have there been attempts to quantify pollen ingestion by individual larvae. Other studies with bees fed purified $B$. thuringiensis proteins, or pollen from $B$. thuringiensis plants, or bees allowed to forage on B. thuringiensis plants in the field have confirmed the lack of effects (O'Callaghan et al. 2005).
The effects of other insect-resistant proteins and GM plants on honeybees and bumble bees have been investigated in a series of laboratory, glasshouse, and field-based studies reviewed recently. Of these, only serine proteinase inhibitors (PIs) affect honey bees and bumblebees, causing changes in bee digestive proteases and some reductions in survival when ingested at high concentrations. Whether bees in the field would be exposed to such levels of PIs will depend on expression levels in the pollen of the GM PI-plants and the amounts and types of pollen foraged (Groot and Dicke 2002).

When transgenic maize (Zea) pollen was deposited on leaves of nearby Asclepias syriaca, larvae of the Monarch butterfly (Danaus plexippus) showed high mortality (Sears et al. 2001). However, B. thuringiensis Cry1 A(c) transgenic pollen and nectar were found not to affect a wide range of other flower-visiting insects tested and appear to have no effect on hive bees. Oil-seed rape has been modified with other toxins such as chitinase, beta1,3 glucanase, and cowpea trypsin inhibitor, which are expressed in pollen and nectar. These are non-lethal to Apis, but the latter two compounds were shown to have a detrimental effect on bee behavior (Picard-Nizou et al. 1997).

\section{Ecological interactions among crops, weeds, and beneficial insects}

Agricultural intensification has led to a more homogenous landscape characterized by large crop fields and fewer noncultivated habitats. In this context, many weed species within and around fields offer many important requisites for beneficial insects such as pollen, or nectar as well as microhabitats that are not available in weed-free monocultures (Landis et al. 2005). In the case of natural enemies, weeds in addition provide alternative prey/hosts, and this is important because many insect pests are not continuously present in annual crops, and their predators and parasitoids must survive during their absence (Altieri and
Fig. 2 Honey bee (left) and syrphid fly (right) visiting flowers
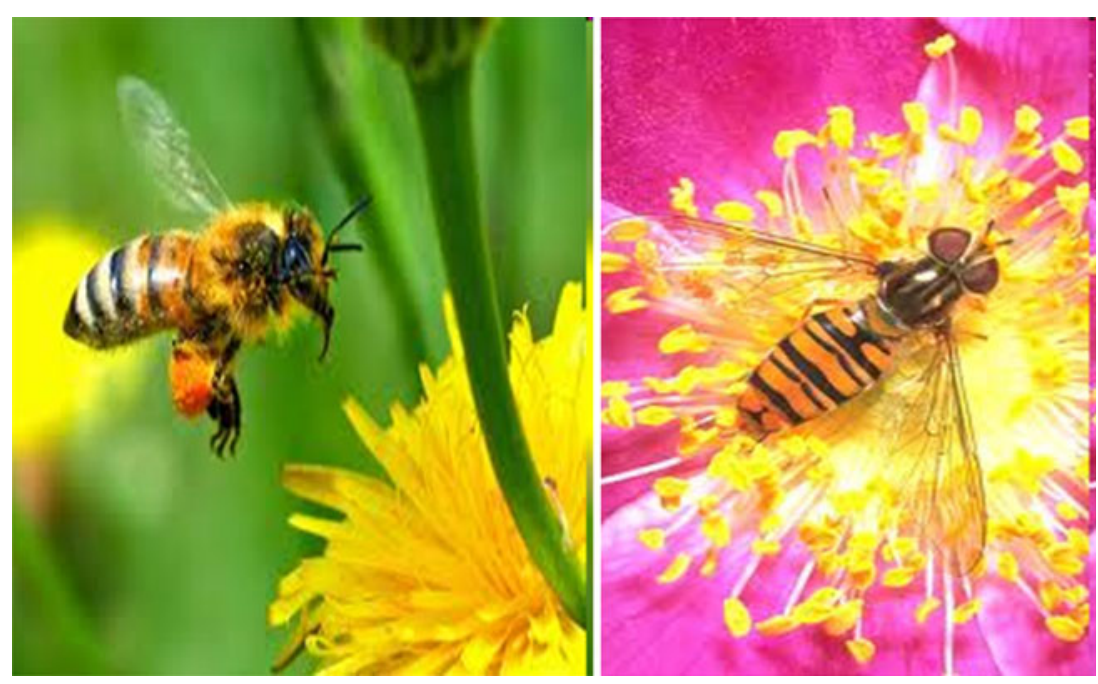
Letourneau 1982). The value of non-crop forage plants, often regarded as weeds, is very high to pollinators and farmers. In situations where such alternative forage, which would normally be available before, during, or after the bloom of the crop, has been eliminated or reduced in abundance, the natural assemblages of pollinators suffer, and so do crop yields (Keams and Inouye 1997).

Weeds usually provide alternative food resources (pollennectar, alternate prey/host) thus aiding in the survival of viable populations of pollinators and natural enemies (Fig. 2). The beneficial entomofauna associated with weeds has been surveyed for many species, including the perennial stinging nettle (Urtica dioica), Mexican tea (Chenopodium ambrosioides), camphorweed (Heterotheca subaxillaris), and a number of ragweed species (Altieri and Nicholls 2004). Perhaps the most exhaustive study of the fauna associated with various weeds is the work of Nentwig (1998) in Berne, Switzerland, where they monitored the insects associated with 80 plant species sown as monocultures in a total of 360 plots. According to this survey, weed species are insect habitats of widely differing quality. Plants such as chervil of France (Anthriscus cerefolium), comfrey (Symphytum officinale), and gallant soldier (Galinsoga ciliata) have extremely low arthropod populations of less than 15 individuals $/ \mathrm{m}^{2}$, whereas most plants have 100-300 arthropods $/ \mathrm{m}^{2}$ according to the D-vac sampling method used by these researchers. Five hundred or more arthropods were found per square meter on poppy (Papaver rhoeas), and tansy (Tanacetum vulgare), and the crops rape (Brassica napus) and buckwheat (Fagopyrum esculentum), which may grow adventitiously in areas previously sown to these plants. Considering the trophic structure of the arthropod communities, results were even more striking. Of all arthropods, phytophagous insects constituted about $65 \%$ of the species (most values between $45 \%$ and $80 \%$ ) but the composition of the remaining arthropods varied greatly among pollinators, predators, and parasitoids. In the former USSR, Naumkin (1992) found 83 species of insect pollinators from five orders associated with buckwheat. The various orders included Hymenoptera (32 species), Diptera and Coleoptera (30 and 11 species respectively), and Lepidoptera and Neuroptera with seven and three species each. Main family groups included Syrphidae (19 species), Bombinae (15), Apoidea (13), Coccinellidae (16), Stratiomyidae, Vespidae, and Chrysopidae with three to four species each.

It is well known that Hymenopteran parasitoids require food in the form of pollen and nectar, to ensure effective reproduction and longevity. van Emden (1965) demonstrated that certain Ichneumonidae, such as Mesochorus spp., must feed on nectar for egg maturation, and Leius (1967) reported that carbohydrates from the nectar of certain Umbelliferae are essential for normal fecundity and longevity in three Ichneumonid species. In studies of the parasitoids of the European pine shoot moth, Rhyacionia buoliana, Syme (1975) showed that fecundity and longevity of the wasps Exeristes comstockii and Hyssopus thymus were significantly increased with the presence of several flowering weeds.

Wildflowers such as Brassica kaber, Barbarea vulgaris, and wild carrot (Daucus carota) provided nectar flowers to female parasitoids of Diadema insulare an ichneumonid parasitoid of the diamondback moth (Idris and Grafius 1995). An increased fecundity and longevity of the wasp was correlated with flower corolla opening diameter and flower shading provided to the parasitoid by the plants. Because of its long flowering period over the summer Phacelia tanacetifolia has been used as a pollen source to enhance Syrphid fly populations in cereal fields in the UK (Wratten and van Emden 1995).

Spectacular parasitism increase has been observed in annual crops and orchards with rich undergrowths of wild flowers. In apple, parasitism of tent caterpillar eggs and larvae and codling moth larvae was 18 times greater in those orchards with floral undergrowths than in orchards with sparse floral undergrowth (Leius 1967).

Soviet researchers at the Tashkent Laboratory (Telenga 1958) cited lack of adult food supply in deciduous fruit orchards as a reason for the inability of Aphytis proclia to control its host, the San Jose scale (Quadraspidiotus perniciosus). The effectiveness of the parasitoid improved as a result of planting a Phacelia sp. cover crop in the orchards. Three successive plantings of $\mathrm{Pha}$ celia increased scale parasitization from $5 \%$ in clean cultivated orchards to $75 \%$ where these nectar producing plants were grown. Russian researchers also noted that Apanteles glomeratus, a parasite of two cabbage worm species (Pieris spp.) on crucifer crops, obtained nectar from wild mustard flowers. The parasites lived longer and laid more eggs when these weeds were present. When quick-flowering mustards were actually planted in the fields with Cole crops, parasitization of the host increased from $10 \%$ to $60 \%$ (Telenga 1958).

Although the above studies report on dependence on flowers by a number of Hymenoptera parasitoids of pests, this dependency is a universal phenomenon among a great variety of pollinators (Kevan 1983).

\section{Agronomic strategies to encourage weeds beneficial to pollinators}

Because wild pollinators generally cannot be introduced suddenly to agricultural systems in adequate numbers, managing farm conditions may prove a more successful approach than managing pollinators themselves. The most effective farm practices will be those directly related to the life cycle of bees:

a. Tillage, mulching, cover crops that may affect nesting sites and survival of immature bees

b. Within and surrounding farm diversity that determine continual food supply and habitat conditions 
c. Pesticide use that may remove floral resources (herbicides) or directly poison adults (insecticides)

d. Farm size and the nature of the surrounding habitats are important but are less prone to be manipulated by farmers.

In this article, we pay special attention to the encouragement of weeds within and in the crop field borders. As discussed above, much evidence suggests that encouragement of specific weeds in crop fields may improve the abundance and diversity of beneficial insects, including pollinators (Altieri and Whitcomb 1979a). Naturally, careful manipulation strategies need to be defined in order to avoid weed competition with crops and interference with certain cultural practices (Zimdahl 1980). Economic thresholds of weed populations, as well as factors affecting crop-weed balance within a crop season, need to be defined for specific cropping systems (Bantilan et al. 1974). Defining periods of weed-free maintenance in crops so that densities of desirable weed numbers do not surpass tolerable levels during the critical period of competition might prove to be a significant compromise between weed science and entomology, a necessary step to further explore ways to enhance beneficial insects in agroecosystems. Shifting the crop-weed balance so that beneficial weed presence is achieved and crop yields are not economically reduced may be accomplished by carefully using herbicides or selecting cultural practices that favor the crop cover over weeds (Altieri and Nicholls 2004).

\subsection{Establishing or restoring weedy hedgerows}

In intensive agricultural areas where weeds are not tolerated within large fields, a priority should be to conserve or reinforce the hedgerows and their constituent weedy plants such as nettles, wild umbelliferae, comfrey, wild clovers, etc., as well as herbaceous plants, especially the more specialist long-corolla perennials that tend to have more nectar than annuals (Corbet 1995). In addition to pollen and nectar for adults and food plants for larvae, hedgerows provide shelter and nesting sites for many pollinators (Fig. 3). Many hedgerows supply the substrates that provide nesting sites for various pollinator species. Such substrates include undisturbed areas and bare ground, dry branches or logs, or sandy or earth bank (Willmer 2011). Many crops grown near fragments of native forests get significant pollination benefits, as shown in grapefruit crops closed to subtropical forests in Argentina, where Chacoff and Aizen (2006) found greater pollinator diversity close to the margins.

There are now available many "grass and wildflower" and "nectar and pollen" seed mixtures (which contain some plants considered weed species) that can be planted around agricultural plots and which can attract significant numbers of bees and hoverflies (Pontin et al. 2006). Many of these mixtures contain specific host plants for the larval stages of butterflies, moths, and some beetles (Fig. 4).

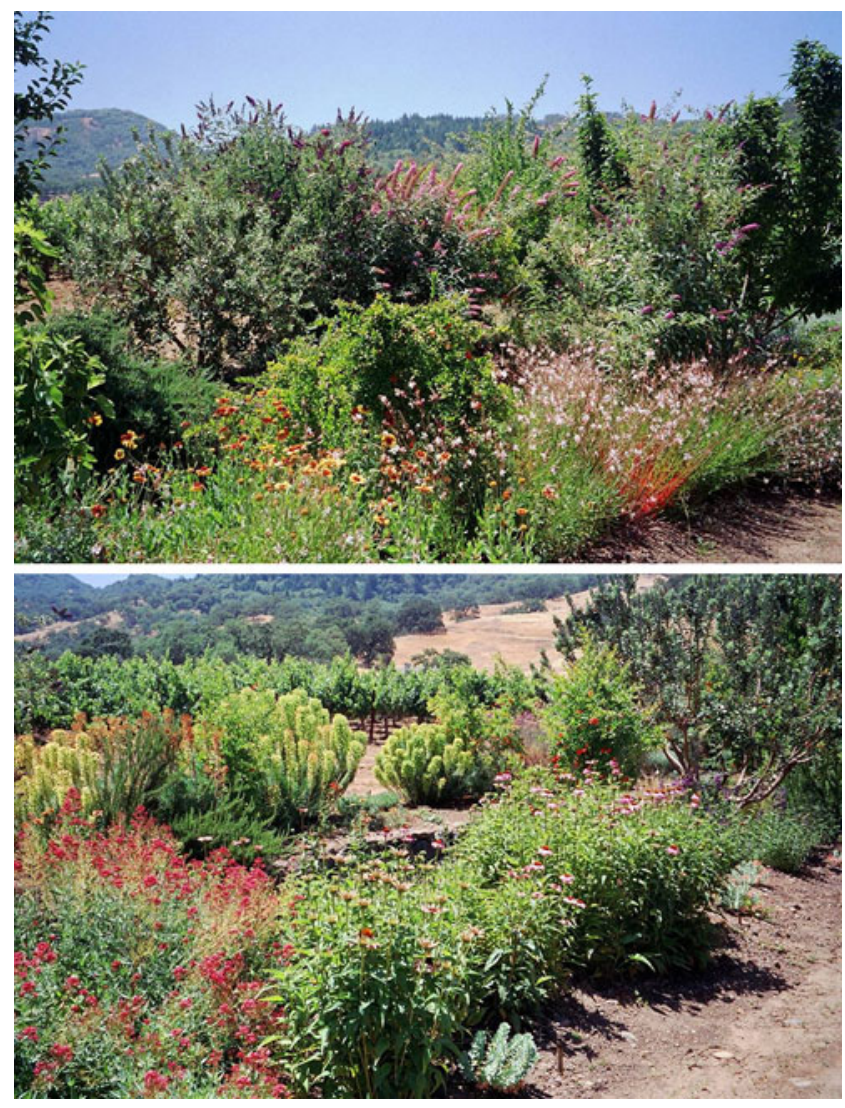

Fig. 3 Hedgerows enriched with native plants that provide a flowering succession throughout the year

\section{Maintaining tolerable levels of weed densities in the field}

Agroecological management can be directed at maintaining tolerable levels of desirable weeds that support populations of beneficial insects. Farmers can also introduce certain

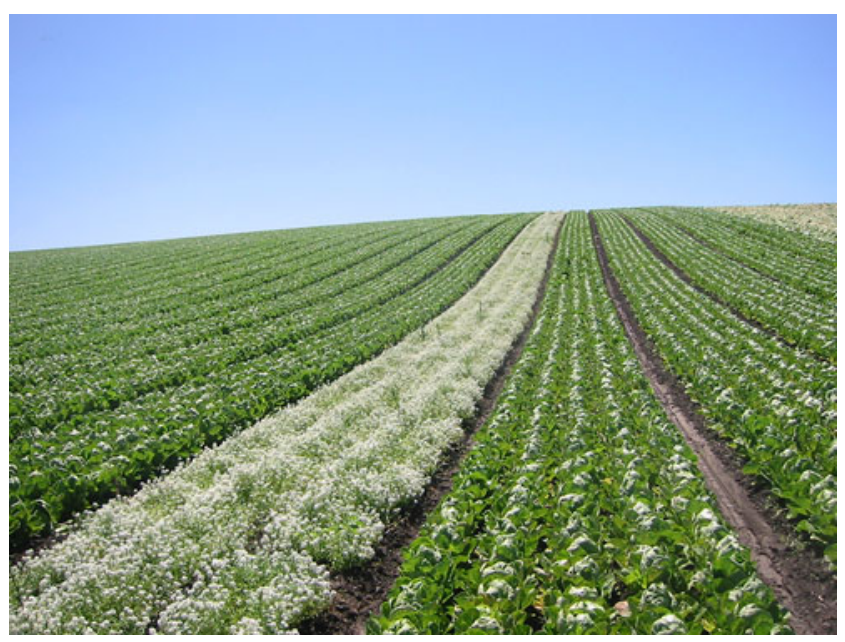

Fig. 4 A strip of flowering alyssum in a lettuce field to attract syrphid flies in California 
flowering weeds by sowing mixtures within or around fields. Among the most amenable weed management approaches compatible with pollinator management are:

\subsection{Defining weed thresholds and critical competition periods}

To avoid excessive losses from weed interference, the determination of weed thresholds can be useful. A competitive threshold can be defined as the weed density and duration of interference above which crop yield is reduced significantly, generally above $20 \%$. The period threshold has been defined as the time period early in the crop season before any crop yield loss occurs due to weed interference. The importance of the period threshold lies in the understanding of the critical period during which remedial control action may be taken to avoid yield loss. This period varies from around 2 to up to 8 weeks after crop emergence, depending on the crop species, weed species complex, and environmental and soil conditions. Period threshold may also be applied to define the time during which weed control must be maintained early in the crop cycle to avoid yield loss from weeds that may emerge later in the season (Oliver 1988). It is difficult to work with weed thresholds because, in general, there are many weed species occurring at the same time and mono- or oligo-specific weed stands are exceptions. The critical period is a more practical approach to maintain tolerable levels of desirable weed species.

The critical period can be determined for each farming system by removing weeds that emerge in the crop at various times during the growing season, or conversely are allowed to compete throughout the season (Fig. 5). The application of this method consists in

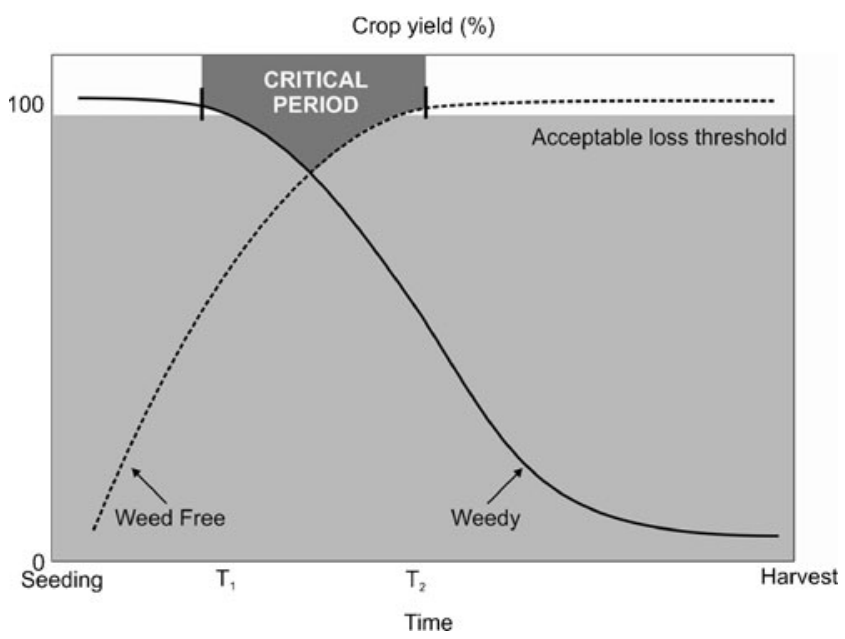

Fig. 5 The influence of time of weed emergence or weed removal on percent crop yield and magnitude of the critical period keeping crops free of weeds during the critical period and then allows flowering weeds to grow thus providing resources to pollinators but without impacting crop production. For less competitive crops, the longer the critical period (6-10 weeks) which means that flowering weeds will not be present until after the 6-10-week period. In the case of crops like onion that do not tolerate weeds at all during the whole growing cycle, crop-pollinator-friendly weeds must be kept on the field edges or at reserved spots in the field where they do not compete with the crop.

All weed scientists agree that, to define the maximum period that weeds can be tolerated without affecting final crop yields, or the point after which weed growth does not affect final yield is of key importance. In general, weeds that emerge earlier in the growing season are more damaging to crop yields than are populations that emerge later. On the other hand, crops differ in their sensitivity to different durations of weed competition, but most are most susceptible during the first third of their life cycle. The guiding principle here is to delay weed emergence relative to crop emergence (Liebman and Gallandt 1997). Duration of weed competition data for particular crops has been compiled by Zimdahl (1980), and critical weed-free maintenance periods have been identified for various crop-weed associations. The important question becomes how long exclusion efforts must be maintained before they can be relaxed, so those weeds emerge and provide the desired entomological benefits. As might be expected, the critical weed-free period for a given crop varies considerably among sites and years, due to climate and edaphic conditions affecting crop and weed emergence and growth rates, weeds species composition, and weed density.

A threshold based on weed density that maintains a certain number of weed plants per defined area (number plants/meter row or square meter) is more difficult to practically attain. As a weed becomes established in the crop row, it occupies a given space within the crop canopy. The area occupied by the weed is called the area of influence, and as this area increases, the weed species becomes potentially more competitive. In soybean, yield losses occur when cocklebur is at distances of less than $25-50 \mathrm{~cm}$ from soybean. Using this information, the tolerable densities of a particular weed species can be determined for each particular crop (Fig. 6) (Coble and Mortense 1992).

\subsection{Including forage crops in rotations}

By rotating crops with different planting dates and growth periods, contrasting competitive characteristics and dissimilar management practices, field weed composition and 


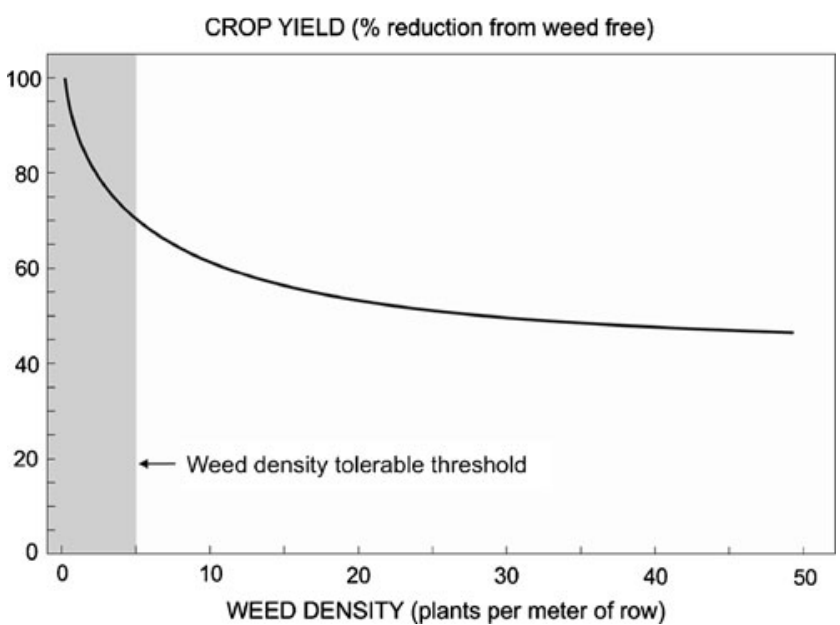

Fig. 6 Relationship between crop yield and weed density to determine tolerable weed thresholds

abundance can be altered. Densities of many weed species remain stable or decline when crops are rotated (i.e., wheat-oil seed rape, maize-soybean, winter wheat), whereas the densities of weeds increase rapidly when a crop (wheat, maize, etc.) is grown continuously. The inclusion of perennial forage crops in rotations may offer opportunities to further weed suppression. Because little soil disturbance occurs in forage crops, the germination of many weed species is suppressed relative to tilled conditions, and consequently, few new weed seeds may be added to the soil seed bank (Liebman and Dyck 1993). Many forage crops themselves generally provide abundant resources for pollinators.

\subsection{Designing competitive crop mixtures}

Effective weed suppressive intercropping systems are those that capture a greater share of the available resources (nutrients, water, sunlight, etc.) that otherwise weeds would utilize. Many studies have shown that a variety of intercrops intercept more light, capture greater quantities of macronutrients and water, and produced higher yields while containing lower weed densities than corresponding monocultures. Although these systems are well suited to small-scale laborintensive farming systems, certain crop mixtures (i.e., maizesoybean strip-cropping or mixtures of small grains with red clover) are compatible with farm machinery and thus can be adapted in large-scale systems (Liebman and Davis 2000).

Many farmers use cover crops (usually legumes as green manures) as a rotational component, which suppress weeds by competing for resources, changing environmental factors that affect weed germination and by releasing phytotoxins (i.e., rye, fodder radish) that inhibit weed germination and growth. Through this mechanism, some species such a hairy vetch can suppress weed density by $70-80 \%$ (Liebman and Gallandt 1997).
It is important to consider that the effects of cultural practices on weeds manifest differently depending on the type of farming system considered. For example, compared with conventional agriculture, in organic agriculture, the effects of cultural practices (e.g., fertilization and direct weed control) on crop-weed interactions usually manifest themselves more slowly. In such systems, weed management should be tackled in an extended time domain and needs deep integration with the other cultural practices, aiming to optimize the whole cropping system rather than weed control per se. Small and/or organic farmers using direct (physical) weed control can only be successful if preventive and cultural weed management is applied to reduce weed emergence (e.g., through appropriate choice of crop sequence, tillage, smother/cover crops) and improve crop competitive ability (e.g., through appropriate choice of crop genotype, sowing/ planting pattern, and crop diversity (Barberi 2002).

\subsection{Attaining desirable weed species composition} in the field

In addition to reducing weed densities to levels that minimize the competitive interference of weeds, changes in the species composition of weed communities are desirable to ensure the presence of plants that attract beneficial insects. Manipulation of weed species composition can be achieved by several means (Altieri and Whitcomb 1979b; Altieri and Letourneau 1982):

\subsubsection{Changes of the levels of key chemical constituents in the soil}

The local weed complex can be affected indirectly by the manipulation of soil fertility. Fields in Alabama with low soil potassium were dominated by buckhorn plantain (Plantago lanceolata) and curly dock (Rumex crispus), whereas fields with low soil phosphorus were dominated by showy crotalaria (Crotalaria spectabilis), morning glory (Ipomoea purpurea), sicklepod (Cassia obtusifolia), Geranium carolinianum, and coffee senna (Cassia occidentalis) (Hoveland et al. 1976). Soil pH can influence the growth of certain weeds. For example, weeds of the genus Pteridium occur on acid soils while Cressa sp. inhabits only alkaline soils. Other species (many Compositae and Polygonaceae) can grow in saline soils (National Academy of Sciences 1969).

Studies conducted with synthetic fertilizers indicate that they can increase both the rate and total amount of weed germination and may promote more weed growth than crop growth. $\mathrm{N}$ application increased Avena fatua panicle production by $140 \%$ and decreased wheat yield by $49 \%$ compared with unfertilized treatments. Timing of $\mathrm{N}$ fertilizer 
application can affect crop-weed competition, and most studies show that delayed fertilizer applications tend to increase crop biomass while reducing weed biomass (Liebman and Davis 2000).

Organic materials (compost, crop residues, etc.) function as slow-release nutrient sources. If patterns of nutrient release can be predicted and regulated effectively, it may be possible to satisfy the nutrient requirements of large-seeded crops, while stressing small-seeded weeds early in the growing season (Liebman and Dyck 1993).

\subsubsection{Use of herbicides}

Repeated herbicide treatments can cause a shift in weed populations, or select for the development of resistant weed biotypes at the expense of susceptible community members (Horowitz et al. 1962).

Buchanan (1977) has published a list of herbicides that suppress certain weeds while encouraging others. When a maximum rate of 0-6 kg/ha of trifluralin (a,a,a-trifluoro-2, 6-dinitro- $N, N$-dipropylp-toluidine) is applied before sowing, populations of velvetleaf (Abutilon theophrasti), jimson weed (Datura stramonium), Venice mallow (Hibiscus trionum), and prickly sida (Sida spinosa) can be grown among cotton and soybeans without the presence of other unwanted weed species. This strategy is agronomically acceptable as long as the weeds that survive the herbicides appear after the critical period. Although most examples cited by Buchanan (1977) relate to weed-control studies, similar methods may be developed to favor particular beneficial weeds in order to achieve early increases of beneficial insect populations.

As weed species differ in their sensitivity towards various active ingredients, they are differentially controlled by the same herbicide treatment. Herbicides are normally selective against certain crop species, but also less active on some weed species. Against this background, researchers in UK (Ulbert et al. 2010) tested three selective herbicides with different active ingredients (amidosulfuron + iodosulfuron, fluroxypyr, mecoprop-P) at two application rates. They analyzed cover of selected focal species (Centaurea cyanus and $P$. rhoeas) as well as weed species richness, winter wheat yield, and weed community composition as influenced by herbicide treatments. Herbicide treatments involving fluroxypyr generally allowed for the selective retention of the regionally threatened weed species $C$. cyanus and $P$. rhoeas as a beneficial species of high value for associated trophic level and provided considerable control of the competitive species Gallium aparine. Researchers concluded that herbicides with a high specificity provided a valuable contribution to the development of environmentally targeted weed management systems, while enhancing the ecological benefits derived from more desirable weeds.
No doubt that herbicide treatment significantly affect weed species composition by controlling pernicious weeds potentially retaining beneficial or rare species occurring at moderate densities (Clements et al. 1994). Of course, such approach has no applicability in organic farming systems or by resource-poor farmers that cannot afford the chemical inputs.

\subsubsection{Direct sowing}

Perhaps the best possibility to ameliorate the situation for pollinating insects in the modern agricultural landscape is to enrich remaining field margins sowing plants, create new zones with permanent vegetation, or sow weed species mixtures as strips every so many rows within crop fields (Fig. 7). In Sweden, the communities of pollinating insects in reclaimed field margins sown with specific weed flowers were compared with those of a margin with a naturally diverse flora and an adjacent pasture. The sown leguminous plants were very attractive to most insect groups, especially bees and bumble-bees, and their pollen constituted an important part of the bees' total catch (Hausammann 1996). The vegetation established by spontaneous succession especially attracted Syrphidae and other groups of Diptera. Butterflies were found in all vegetation types.

In Switzerland, researchers have long investigated the use of weed strips sown within crop fields and composed of more than 25 herbaceous plants, including annual, biennial, and perennial plants (for example Sinapis alba, C. cyanus, Oenothera biennis, Leucanthemum vulgare, etc.). The main goal is to provide to beneficial insects a continuous offer of flowering herbs over the whole growing season (Nentwig et al. 1998).

In the UK, plots sowed to mixtures of six annual flowering plant species: borage (Borago officinalis), buckwheat (F. esculentum), cornflower (C. cyanus), mallow (Malva

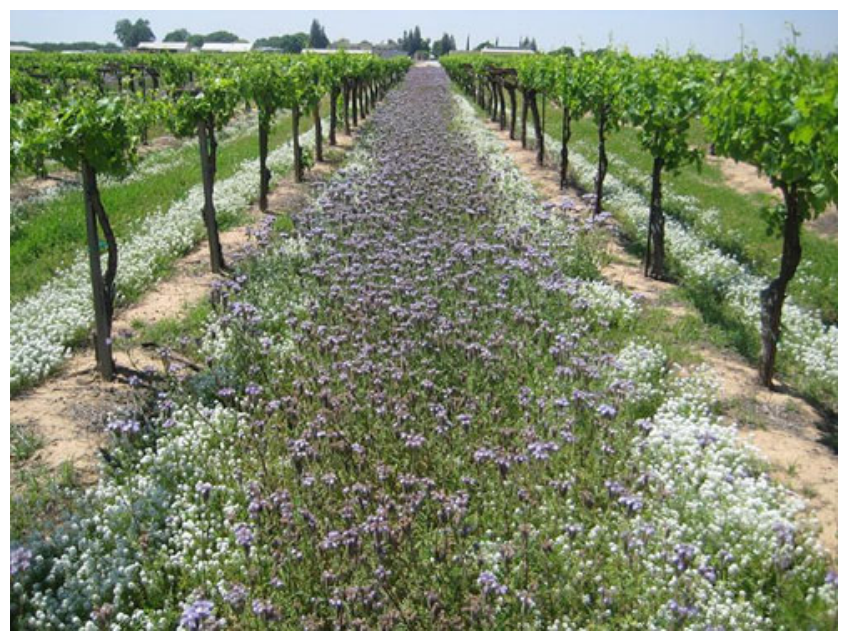

Fig. 7 Flowering cover crops in a California vineyard to enhance resources for beneficial insects 
sylvestris), marigold (Calendula officinalis), and phacelia $(P$. tanacetifolia) in different proportions attracted a diversity of flower-visiting insects. Among observed insects were the honeybees and eight species of bumble bee among 16 species of aculeate Hymenoptera, 17 species of Diptera, mostly syrphids, and six species of Lepidoptera. Sequential sowings provided nectar and pollen from early summer to late autumn during the period after arable crops had finished flowering and food for pollinators was scarce. Different insect species were favored by different sowing-dates and plant species (Carreck and Williams 2002).

The application of this method, however, demands careful investigation of certain weed-seed germination requirements. Some seeds remain in enforced dormancy and germinate only under certain environmental conditions. Most weed seeds have specialized requirements for germination, making it difficult to sow weeds for experimental purposes (Anderson 1968). Nevertheless, today, it is possible to find in the market many weed seed mixtures (mostly flowering plants) that are recommended for planting in and around crop fields to create habitats for beneficial insects.

\subsubsection{Soil disturbance}

The weed species composition of recently plowed cropped fields can be manipulated by changing the season of disturbance. In northern Florida, field plots plowed at different times of year exhibited different weed species composition. Within these plots, populations of herbivorous insects fluctuated according to composition and abundance of weed hosts. Large numbers of chrysomelids and leafhoppers were collected in treatment plots where preferred weed hosts reached high cover values. As these herbivores served as alternative prey, the number of predaceous arthropods feeding on those herbivores varied in direct proportion to the size of populations of their preferred herbivorous prey as determined by the presence of weed hosts and the season of plowing (Altieri and Whitcomb 1979b). The authors proposed plowing strips of land within a crop in different seasons to encourage specific weeds that, in turn, provide an alternative food and habitat to specific predators, if this is done early in the season, a balance of natural enemies can be maintained in the field, before outbreaks of pest species occur.

\subsubsection{Modifying weed spatial patterns}

It may be possible to influence weed spatial distributions and promote weeds to occur in clumps within fields rather than uniformly distributed. For a given average density over a broad area, clumped weeds are expected to be less damaging to crop yield than are randomly or evenly distributed weeds (Aldrich 1984). Clumped weeds in a field spot may reduce yields in the local area, but provide a source of beneficials that colonize the rest of the field from the clump.

\section{Practical tips for encouraging pollinator-friendly weeds}

One of the challenges that bees face in agricultural landscapes is a lack of season-long food sources (Bohart 1972). Large monocultures of bee-pollinated crops like almond, canola, or watermelon, may provide a few weeks of abundant food, but a lack of within field or adjacent wild plants blooming before and after the main crop blooms can result in a decline of healthy pollinator numbers (Goulson 2003). As it has been explored in this paper, encouraging blooming weeds or establishing diverse plantings can provide the floral diversity to support resident pollinators (Fig. 8). Bee diversity is often maximized in landscapes where 15 or more flowering plant species are present, as different bees have different flower preferences, this season-long food supply is especially critical early and late in the year (Willmer 2011). Native bees remain dormant throughout the winter and often need immediate food sources upon emergence in the spring. Bees that over-winter as adults, like bumble bees, often need late-season nectar sources to build up their energy reserves for the long winter. Similarly, honeybees spend winter inside the hive living off honey from nectar they collected over the summer months. Without enough honey, honeybees can starve over the winter resulting in the entire hive dying off.

Since the most obvious need for pollinating species is a diversity of nectar and pollen sources, it is important to consider the following when choosing plants (including selected weedy species) for the farm (Bohart 1972; Sheperd et al. 2003):

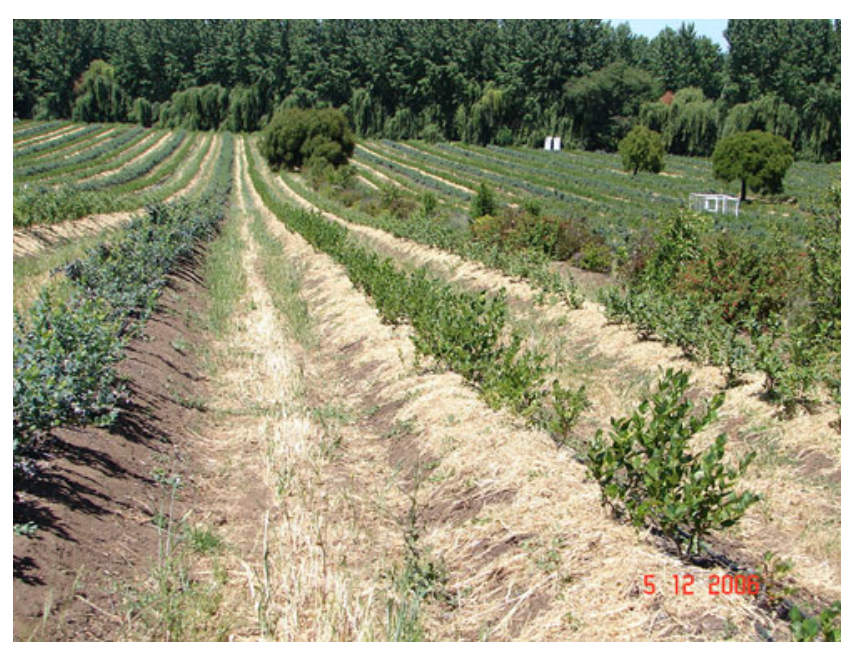

Fig. 8 Corridor of flowering shrubs that cuts across a blueberry field in Chile 
- Choose plants that flower at different times of the year to provide nectar and pollen sources throughout the growing season.

- As a general rule, allow a minimum of three plant species that bloom at any given time during the growing season; spring, summer, and fall.

- Encourage combinations of annuals and perennials.

- Provide a variety of flower colors and shapes to attract different pollinators.

- Encourage plants in clumps, rather than single plants, to better attract pollinators.

- Provide weed and floral diversity as strips every few crop rows or as mixtures in field margins.

- Whenever possible, choose native plants. Native plants will attract more native pollinators and can serve as larval host plants for some species of pollinators.

- In addition to needing season-long food, nesting locations are important. Since the majority of native bees nest in the ground, farming practices that inhibit or destroy nests, like the widespread use of plastic mulch or extensive tilling should be avoided. Often times, diverse farms with a variety of landscape features including patches of bare soil, piles, or hedges of stone and clump-forming grasses can provide ample nest habitat.

Also, cropping systems can be managed to enhance environmental opportunities for insect pollinators. For example, including forage plants as part of a normal crop rotation can be very desirable. Clovers benefit soil quality but also support bees and some longer-tongued flies. Some suitable intercropping systems that include a flowering crop are good for encouraging hoverflies and other species. Some intercropping systems that include a tall and a shorter crop (i.e., maize and bean polycultures) can help provide an ideal microclimate within the system, so that pollinating insects can maintain their thermal and water balance more easily as well as moving between plants more effectively (Willmer 2011).

\section{Costs-benefits to crop productivity of promoting pollinator-friendly weeds}

Unquestionably, weeds stress crop plants through interference processes. However, substantial evidence suggests that weed presence in crop fields cannot be automatically judged damaging and in need of immediate control. In fact, crop-weed interactions are overwhelmingly site-specific and vary according to plant species involved, weed densities, time of competition in relation to crop cycle, environmental factors, and management practices. Similarly, weed control methods cannot be solely rated on the basis of their effectiveness, because factors such as access (to mechanical implements, hoes, herbicides), cost, resulting net income, timeliness of operations, and alternative uses of labor are also key in the selection of chemical, mechanical, or manual control tactics. There is also at issue the question of valuing of ecosystem services (pollination) that may be lost when removing weeds, even if the control method proves economically more profitable. So, even if farmers realize that selected weeds may provide valuable forage resources to pollinators that will benefit their crops, choosing hand weeding to selectively remove weeds to leave beneficial ones may prove to be considerably more costly than the price of using herbicides, therefore hand weeding may at first glance not seem to be a viable option. However, herbicide applications generally remove all weeds, including pollinator-friendly weeds. Weed control and the removal of alternative foraging resources could easily offset the economic advantages of herbicides, especially in the case of a pollinator-dependent crop. The absence of bees in a flowering weed-free field can reduce yields considerably as demonstrated in experiment where faba bean plants caged without honeybee produced $25 \%$ less pods than plants not isolated from pollinating insects (Al Ghamdil 2003). Various authors have recorded 19-37\% increase in yield of several crops by using honeybee as crop pollinators (Allen-Wardell et al. 1998; Klein et al. 2007). Thus, the economics of a weed control method have to be balanced against the needs of crops for pollinators. It is important to make sure that provision of flowering weeds will not reduce crop yields, otherwise the advantages of conserving pollinators would be offset. This is an area of research that needs further attention.

Apparently, more data are available on calculating the benefits of greater pollination from leaving more uncultivated land (dominated by blooming weeds) around crop fields. The best study available exploring the potential economic benefit of uncultivated area for pollinators were conducted in a typical canola Canadian agroecosystem. Mean seed set in openpollinated canola fields was $18.1 \pm 0.2$ seeds/pod. Mean amount of uncultivated land within $750 \mathrm{~m}$ of field edges was $91.1 \pm$ 12.0 ha ( $n=22$ fields). The rest was composed primarily of tilled field crops. In 2002 and 2003, the transgenic (GMHT) and conventional varieties in the study area yielded an average of $1,120,1,568,1,344$, and 1,568 kg/ha, respectively. Taking an average yield of $1,400 \mathrm{~kg} / \mathrm{ha}$, a typical quarter section (64 ha) of canola would yield $89,600 \mathrm{~kg}$. Prices for canola seed have fluctuated between US\$ 0.22 and $0.39 \mathrm{~kg}^{-1}$ for the last 5 years. Using a typical but conservative price estimate for the 2002 and 2003 seasons of US\$ $0.27 \mathrm{~kg}^{-1}$, gross revenue was US\$ 24,192 per quarter section. Approximately US\$17,000 of this was input costs, resulting in a profit of US\$ 7,192 per section.

From this study area, a typical agricultural landscape with canola on a scale of $4 \mathrm{~km}^{2}$ could have five $800 \times 800 \mathrm{~m}$ canola fields. If all five fields had approximately 64 ha of uncultivated land within $750 \mathrm{~m}$ of field edges, profit per field, at $1,335 \mathrm{~kg} / \mathrm{ha}$ yield and a market value of US\$ $0.27 \mathrm{~kg}^{-1}$, would be US\$ 6,069. The profit from the five canola fields in this landscape would be US\$ 30,345 . 
However, if a central section of 64 ha had not been cultivated or was allowed to revert to a semi-natural state, there would be 128 ha of uncultivated land within $750 \mathrm{~m}$ from the four remaining cultivated canola field edges, and the bee abundance index would increase from a mean 30.1 to 63.9 in each field, with a corresponding pollination deficit change of -6.7 to -4.9 , an increase of 1.8 seeds/pod. Yield would increase from 1,335 to $1,467 \mathrm{~kg} / \mathrm{ha}$, and gross revenue per field would equal US\$25,350. Because wild pollinators provide a 'free' pollination service, input costs per field would remain the same (US\$ 17,000 per quarter section), and profit would be US\$ 8,350 quarter section, a $38 \%$ increase in profit per field. Net value of canola in this second landscape scenario (four fields) would be US\$ 33,400, a $10 \%$ increase in landscape profit over five fields without a central uncultivated area. Harvesting and transport costs may increase slightly with greater yields, but this is not included in the analysis (Morandin and Winston 2005).

Landscape profit rose sharply with an increase from $0 \%$ to approximately $20 \%$ uncultivated land. Rate of profit increase decreased from $20 \%$ to $30 \%$ uncultivated land, indicating that the most benefit of uncultivated land was seen when increasing from low to moderate amounts. Above $32.7 \%$, declining amounts of cultivated canola outweighed the benefits of greater pollination from more uncultivated land. Thus, maximum landscape profit was achieved with just over $30 \%$ of the landscape uncultivated (Morandin and Winston 2006).

The value of wild and/or managed pollinators in commercial crop production has been estimated in many countries using different methods (Free 1993). Ascribed values have varied dramatically depending on the methodology used, with managed honeybee annual values in the USA estimated at between US $\$ 1.6$ billion and US\$14.6 billion. Recently, the annual value of maintaining feral honeybee pollination ecosystem services in Australia by preventing the introduction of varroa mites was calculated as between AUS $\$ 16.4$ and 38.8 million (US\$12.6 and 30.7 million) (Losey and Vaughan 2006; Gallai et al. 2009).

Current methods either underestimate (by equating the value of pollination services to the direct cost of the service) or overestimate the service value (by equating the value of pollination services to the proportion of total production value dependent on insect pollination). To distinguish between the managed and wild components, researchers calculated the value of managed pollination as the proportion of pollination attributed to manage pollinators multiplied by the insect dependent production value. In turn, the value of wild pollination was calculated as the difference between the (total) insectdependent production and managed pollination values. Using this method, the contribution of managed honeybee pollination is found to be between US\$28.0 and 122.8 million, for which only US\$1.8 million is presently being paid. Similarly, the contribution of wild pollinators is found to be between US $\$ 49.1$ and 310.9 million for which there is no direct payment from producers. These values illustrate the importance of maintaining natural and other forage areas for the conservation of insect pollinators (Allsopp et al. 2008).

\section{Conclusions}

Researchers have reported that the area devoted to pollinatordependent crops has increased faster than that of nondependent crops in both the developed and developing worlds. Therefore, the demand for animal pollination services is rising at the same time that pollinator abundance and diversity are declining. Researchers have also found a trend of lower growth rate in yield in crops that depend highly on pollinators compared with those with low or none dependence. All these results could be interpreted as an early warning sign of global pollinator declines effects (Garibaldi et al. 2009).

This pollinator crisis seems more acute in landscapes dominated by annual crops (e.g., grains and oil seeds) as these intensively managed and most highly disturbed monocultures do not provide environmental opportunities for beneficial insects. High levels of disturbance hamper the establishment of pollinator populations, and this could prove critical for some crops, such as canola, flax, safflower, sunflower, tomatoes, peppers, strawberries, and cucurbits. Some cole crops require insect pollination for seed production.

In such areas of intensive farming, field margins, field edges and paths, headlands, fence lines, rights of way, nearby uncultivated patches of land, etc., are important refuges for many pollinators, yet, the value of these areas to agricultural productivity is unknown, and few farmers manage such areas to enhance beneficial entomofauna. Research on agricultural landscapes where pollen deposition and crop yield were positively related to the amount of uncultivated land in proximity to fields, indicates a challenging association between crop production and pollination services provided by wild bees from natural areas.

In most agroecosystems, weeds are ever-present biological components within and around fields, adding to the complexity of interacting trophic levels mediating a number of crop-insect interactions with major effects on final yields. An increasing awareness of these ecological relationships elevates weed management as a key strategy to rectify habitat simplification by increasing vegetational diversity in agroecosystems and thus food resources for beneficial insects. Figure 9 describes strategies on how to encourage desirable flowering weed diversity within and around fields to encourage pollinators as well as other practices that would complement such strategies.

Appropriate management of non-cropped areas to encourage wild pollinators may prove to be a cost-effective 
Fig. 9 Strategies to encourage weed floral diversity within and around crop fields to conserve and enhance insect pollinators

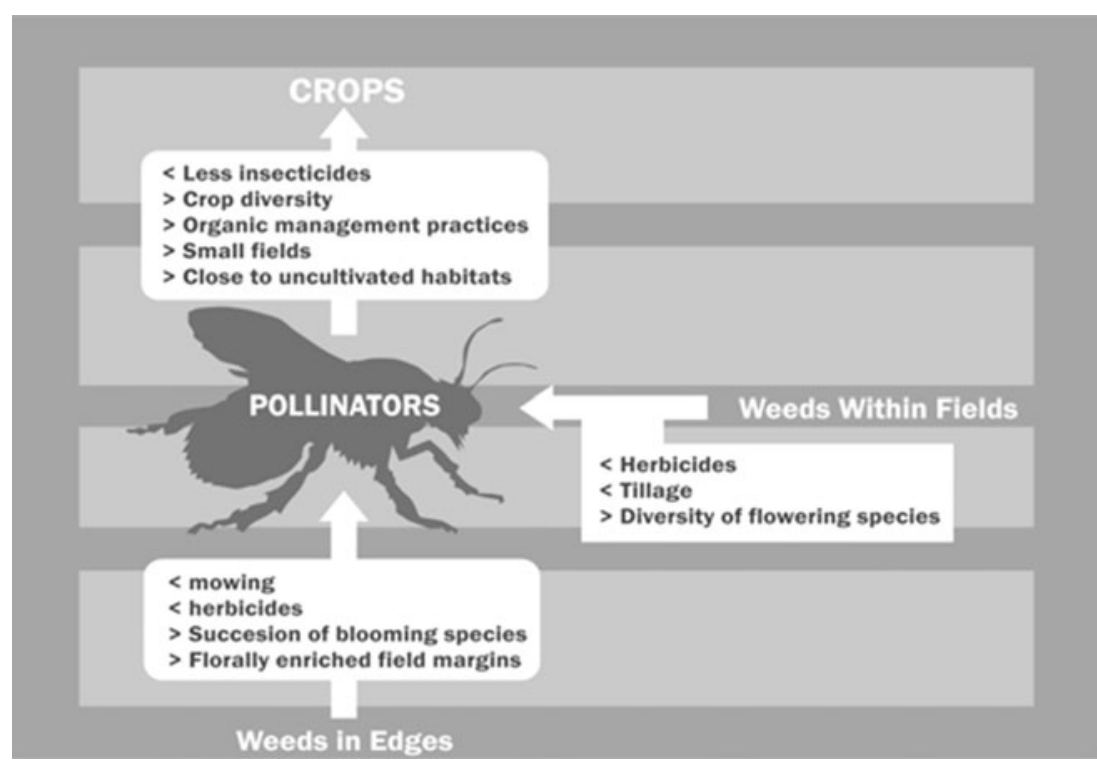

means of maximizing crop yield. Depending on the crops that they grow, farmers may wish to encourage particular species. For example, if they grow field beans in the UK, then they require healthy populations of the long-tongued bumblebees Bombus pascuorum and Bombus hortorum. To encourage them, the farmer might sow wildflower strips containing deep flowers such as white deadnettle (Lamium album) and red clover (Trifolium pratense). Of course, the crops themselves provide vast areas of forage, but only for short periods. However, planting a succession of crops that flower at different times could greatly enhance pollinator abundance while simultaneously maximizing yields.

Similarly, managing flowering weeds at desirable levels to provide alternative forage to pollinators within crop fields has been a totally neglected habitat management tactic for encouraging pollinators. Many advances, however, have been achieved in the area of biological control where entomologists and agroecologists continually manipulate weeds and other floral diversity to enhance predators and parasitoids of pests (Altieri and Nicholls 2004). The same principles that apply in conservation biological control can be applied to enhance pollinator services, thus simultaneously achieving plant protection and pollination.

In annual crops, allowing weed diversity after the critical period of weed competition or providing weeds as field borders or strips every few crop rows has proven to be agronomically feasible. In orchards, cover crop management, although not solely directed at weed control, can enhance soil quality and habitat for beneficial insects, thus positively affecting pollination in many fruit crops. The challenge is to identify a mixture of weed groundcover species that encourage bee visitations without competing with the fruit crop. Of particular importance is to find species that produce an abundance of nectar and pollen, yet flower before and after the fruit crops, thus helping sustain wild bee populations in the local area. A perennial cover crop would permit ground-nesting bees to establish in the orchard.

Clearly, a more comprehensive strategy for managing pollinators in agroecosystems is needed. In addition, to understand the biology of flowers and the behavior of pollinators, it is important to understand how to manage agroecosystems in order to provide nesting habitat as well as continuing alternative sources of forage that can sustain populations of pollinators year around.

So far, weed management with the specific aim of enhancing wild pollinator populations is in its infancy and, at present, is largely based on educated guesswork. Clearly, more research is warranted to advance knowledge on identifying beneficial weed species and ways to sponsor them to attract pollinators while not reducing yields through interference.

\section{References}

Adams JB, Drew ME (1965) Grain aphids in New Brunswick. Ill. Aphid populations in herbicide-treated oat fields. Can J Zool 43:789-794

Aizen MA, Garibaldi LA, Cunningham SA, Klein AM (2008) Long term global trends in crop yields and production reveal no current pollinator shortage but increasing pollinator dependency. Curr Biol 18:1572-1575

Al Ghamdil A (2003) The impact of insect pollinators on yield and yield components of faba bean (Vicia faba L.). Saudi J Biol Sci 10:56-62

Aldrich RJ (1984) Weed-crop ecology-principles in weed management. Breton Publishers, North Scituate

Allen-Wardell G, Bernhardt P, Bitner R, Burquez A, Buchmann S (1998) The potential consequences of pollinator declines on the conservation of biodiversity and stability of food crop yields. Cons Biol 12:8-17

Allsopp M, de Lange WJ, Veldtman R (2008) Valuing insect pollination services with cost of replacement. PLS one 3(9):e3128. doi:10.1371/Journal.pone. 0003128 
Altieri MA, Letourneau DK (1982) Vegetation management and biological control in agroecosystems. Crop Prot 1:405-430

Altieri MA, Nicholls CI (2004) Biodiversity and pest management in agroecosystems. Haworth Press, New York

Altieri MA, Whitcomb WH (1979a) The potential use of weeds in the manipulation of beneficial insects. HortScience 14:12-18

Altieri MA, Whitcomb WH (1979b) Manipulation of insect populations through seasonal disturbance of weed communities. Prot Ecol 1:185-202

Altieri MA, Schoonhoven AV, Doll JD (1977) The ecological role of weeds in insect pest management systems: a review illustrated with bean (Phaseolus vulgaris L.) cropping systems. PANS 23:195-205

Anderson RN (1968) Germination and establishment of weeds for experimental purposes. Weed Science Society of America, Washington

Bäckman JC, Tiainen J (2002) Habitat quality of field margins in a Finnish farmland area for bumblebees (Hymenoptera: Bombus and Psithyrus). Agric Ecosyst Environ 89:53-68

Baliddawa CW (1985) Plant species diversity and crop pest control: an analytical review. Insect Sci Appl 6:479-487

Ball DA (1992) Weed seed-bank response to tillage, herbicides, and crop rotation sequences. Weed Sci 40:654-659

Ball DA, Miller SD (1990) Weed seed population response to tillage and herbicide use in three irrigated cropping sequences. Weed Sci 38:511-517

Bantilan RT, Palada M, Harwood RR (1974) Integrated weed management. I. Key factors affecting weed-crop balance. Phil Weed Sci Bull 1:14-36

Barberi P (2002) Weed management in organic agriculture: are we addressing the right issues. Weed Res 42:177-193

Belfrage K, BJörklund J, Salomonsson L (2005) The effects of farm size and organic farming on diversity of birds, pollinators, and plants in a Swedish landscape. Ambio 8:582-588

Benedek P (1972) Possible indirect effect of weed control on population changes of wild bees pollinating lucerne. Acta Pathol Acad Sci Hung 7:267-278

Benedek P (1996) Structure and density of lucerne pollinating wild bee populations as affected by changing agriculture. Acta Hort 437:353-357

Bohart GE (1972) Management of habitats for wild bees. Proc Tall Timbers Conf Ecol Animal Control Habitat Manag 3:253-266

Buchanan GA (1977) Weed biology and competition. In: Truelove B (ed) Research methods in weed science. 2nd ed. Southern Weed Sci. Soc, Auburn Printing, Inc., Auburn, AL, pp. 25-41

Buchmann SL, Nabhan GP (1996) The forgotten pollinators. Island Press, Washington

Carreck NL, Williams IH (2002) Food for insect pollinators on farmland: insect visits to flowers of annual seed mixtures. J Insect Conser 6:13-23

Carvalheiro LG, Veldtman R, Shenkute AG, Tesfay G, Werner CW, Donaldson JS, Nicolson SW (2011) Natural and within-farmland biodiversity enhances crop productivity. Ecology Letters 14, 251259

Chacoff NP, Aizen MA (2006) Edge effects on flower-visiting insects in grapefruit plantations bordering premontane subtropical forest. J Appl Ecol 43:18-27

Clements DR, Weise SF, Swanton CJ (1994) Integrated weed management and weed species diversity. Phytoprotection 75:1-18

Coble HD, Mortense DA (1992) The threshold concept and its application to weed science. Weed Tech 6:191-195

Corbet SA (1995) Insects, plants and succession: advantages of long term aside. Agric Ecosyst Environ 53:201-217

Dempster JP (1969) Some effects of weed control on the numbers of the small cabbage white (Pieris rapae L.) on Brussels sprouts. J Appl Ecol 6:339-405
Dixon DP, Fingler BG (1982) The effects of the 1981 Manitoba emergency mosquito control program on honey bees. In: Western equine encephilitis in Manitoba. Government of Manitoba, Winnipeg, pp 243-247

Dixon DP, Fingler BG (1984) The effects of the mosquito control program on bees. In: Final technical report on environmental monitoring program for the 1983 spraying of malathion to combat western equine encephalitis. Government of Manitoba, Winnipeg, pp 101-121

Dover JW, Sotherton N, Gobbett K (1990) Reduced pesticide inputs on cereal field margins: the effects on butterfly abundance. Ecol Entomol 15:17-24

Feber RE, Firbank LG, Johnson PJ, Macdonald DW (1997) The effects of organic farming on pest and non-pest butterfly abundance. Agric Ecosys Envir 64:133-139

Flaherty D (1969) Ecosystem trophic complexity and the Willamette mite, Eotetranychus willamettei (Acarine: Tetranychidae) densities. Ecol 50:911-916

Free JB (1993) Insect pollination of crops. Academic, London

Gallai N, Settele JM, Vaissiere BE (2009) Economic valuation of the vulnerability of world agriculture confronted with pollination decline. Ecol Econ 68:810-821

Garibaldi LA, Aizen MA, Cunningham SA, Klein AM (2009) Pollinator shortage and global crop yield. Comm Integ Biol 2:37-39

Goulson D (2003) Conserving wild bees for crop pollination. Food Agric Envir 1:142-144

Groot AT, Dicke M (2002) Insect resistant transgenic plants in a multiple-trophic level. Plant J 31:387-406

Hausammann A (1996) Strip-management in rape crop: is winter rape endangered by negative impacts of sown weed strips? J Appl Ent 120:505-512

Hawes CJ, Haughton JL, Osborne DB, Roy SJ, Clark JN, Perry P, Rothery DA, Bohan DR, Brooks GT, Champion AM, Dewar MS, Heard IP, Woiwod RE, Daniels MW, Young AM, Parish RJ, Scott LG, Firbank B, Squire GR (2003) Responses of plants and invertebrate trophic groups to contrasting herbicide regimes in the farm scale evaluations of genetically modified herbicide-tolerant crops. Phil Trans R Soc Lond B 358:1899-1913

Hole DG, Perkins AJ, Wilson JD, Alexander IH, Grice PV, Evans AD (2004) Does organic farming benefit biodiversity? Biol Cons 122:113-130

Horowitz MT, Blumdel T, Hertz-linger G, Hulin N (1962) Effects of repeated applications of ten soil-active herbicides on weed populations. Weed Res 14:97-109

Hoveland CS, Buchanan GA, Harris MC (1976) Response of weeds to soil phosphorous and potassium. Weed Sci 24:194-201

Idris AB, Grafius E (1995) Wildflowers as nectar sources for Diadegma insulare (Hymenoptera: Ichneumonidae), a parasitoid of diamondback moth (Lepidoptera: Yponomeutidae). Environ Entomol 24:1726-1735

Johansen CA (1977) Pesticides and pollinators. Ann Rev Entomol 22:177-192

Johansen CA, Mayer DF (1990) Pollinator protection: a bee and pesticide handbook. Wicwas Press, Cheshire

Keams CA, Inouye DW (1997) Pollinators, flowering plants, and conservation biology. BioSci 47:297-307

Kevan PG (1983) Insects as flower visitors and pollinators. Ann Rev Entomol 28:407-453

Kevan PG (1999) Pollinators as bioindicators of the state of the environment: species, activity and diversity. Agric Ecosyst Environ 74:373-393

Kevan PG, Plowright RC (1989) Fenitrothion and insect pollination. In: Ernst WR, Pearce PA, Pollock TL (eds) Environmental effects of fenitrothion use in forestry: impacts on insect pollinators, songbirds, and aquatic organisms. Environment Canada, Dartmouth, pp 13-42 
Kevan PG, Greco CF, Belaoussoff S (1997) Log-normality of biodiversity and abundance in diagnosis and measuring of ecosystemic health: pesticide stress on pollinators on blueberry heaths. J Appl Ecol 34:1122-1136

Klein AM, Vaissière BE, Cane JH, Steffan-Dewenter I, Cunningham SA (2007) Importance of pollinators in changing landscapes for world crops. Proc R Soc Lond B Biol Sci 274:303-313

Kremen C, Williams NM, Thorp RW (2002) Crop pollination from native bees at risk from agricultural intensification. Proc Natl Acad Sci 99:16812-16816

Kremen C, Williams NM, Bugg RL, Fay JP, Thorp RW (2004) The area requirements of an ecosystem service: crop pollination by native bee communities in California. Ecol Lett 7:1109-1119

Lagerlof J, Starkb J, Svensson B (1992) Margins of agricultural fields as habitats for pollinating insects. Agric Ecosyst Environ 40:117-124

Landis D, Menalled FD, Costamagna AC, Wilkinson TK (2005) Manipulating plant resources to enhance beneficial arthropods in agricultural landscapes. Weed Sci 53:902-908

Leius K (1967) Influence of wild flowers on parasitism of tent caterpillar and codling moth. Can Entomol 99:444-446

Liebman M, Davis AS (2000) Integration of soil, crop and weed management in low-external input farming systems. Weed Res 40:27-47

Liebman M, Dyck E (1993) Crop rotation and intercropping strategies for weed management. Ecol Appl 3:92-122

Liebman M, Gallandt ER (1997) Many little hammers: ecological management of crop-weed interactions. In: Jackson LE (ed) Ecology in Agriculture. Academic Press, San Diego, pp 291-342

Losey JE, Vaughan M (2006) The economic value of ecological services provided by insects. BioSci 56:311-323

Mackenzie KE, Winston ML (1984) Diversity and abundance of native bee pollinators of berry crops and natural vegetation in the lower Fraser Valley, British Columbia. Can Entomol 116:965-974

Morandin LA, Winston ML (2005) Wild bee abundance and seed production in conventional, organic, and genetically modified canola. Ecol Appl 15:871-881

Morandin LA, Winston ML (2006) Pollinators provide economic incentive to preserve natural land in agroecosystems. Agric Ecosyst Environ 116:292-298

Morandin LA, Winston ML, Abbott VA, Franklin MT (2007) Can pastureland increase wild bee abundance in agriculturally intense areas? Basic Appl Ecol 8:117-124

Moreby SJ, Southway SE (1999) Influence of autumn applied herbicides on summer and autumn food available to birds in winter wheat fields in southern England. Agric Ecosyst Environ 72:285-297

National Academy of Sciences (1969) Insect-pest management and control. Prin Plant Anim Pest Control Ser 3:100-164

Naumkin VP (1992) Species composition of insects- pollinators of buckwheat, pp. 443-446. In: Proc Fifth Inter Symp Buckwheat Res, Agricultural Publishing House, Beijing. Pp. 443-446

Nentwig W (1998) Weedy plant species and their beneficial arthropods: potential for manipulation in field crops. In: Pickett $\mathrm{CH}$, Bugg RL (eds) Enhancing biological control: habitat management to promote natural enemies of agricultural pests. UC Press, Berkeley, pp 49-72

Nentwig W, Frank T, Lethmayer C (1998) Sown weed strips: artificial ecological compensation areas an important tool in conservation biological control. In: Barbosa P (ed) conservation biological control. Academic, New York, pp 133-151

New TR (2005) Invertebrate conservation and agricultural ecosystems. Cambridge University Press, Cambridge

Norris RR (1982) Interactions between weeds and other pests in the agroecosystem. In: Hatfield JL, Thomason IJ (eds) Biometeorology in integrated pest management. Academic, New York, pp 343-406

O'Callaghan M, Glare TR, Burgess EPJ, Malone LA (2005) Effects of plants genetically modified for insect resistance on non- target organism. Ann Rev Entom 50:271-292
Ockinger E, Smith HG (2007) Seminatural grasslands as population sources for pollinating insects in agricultural landscapes. J Appl Ecol 44:50-59

Oliver LR (1988) Principles of weed threshold research. Weed Tech 2:398-403

Perrin RM (1975) The role of the perennial stinging nettle Urtica dioica as a reservoir of beneficial natural enemies. Ann Appl Biol 81:289-297

Picard-Nizou AL, Grison R, Olsen L, Pioche C, Arnold G, PhamDelegue MH (1997) Impact of proteins used in plant genetic engineering toxicity and behavioral studies in the honeybee. $\mathrm{J}$ Econ Entomol 90:1710-1716

Pimentel D (1961) Species diversity and insect population outbreaks. Ann Entomol Soc Amer 54:76-86

Pontin DR, Wade MR, Kehrli P, Wratten SD (2006) Attractiveness of single and multiple species flower patches to beneficial insects in agroecosystems. Annals of Applied Biology 148:39-47

Richards AJ (2001) Does low biodiversity resulting from modern agriculture practice affect crop pollination and yield? Ann Bot $88: 165-172$

Root RB (1973) Organization of a plant-arthropod association in simple and diverse habitats: the fauna of collards (Brassica oleracea). Ecol Monogr 43:95-124

Scott-Dupree CD, Winston ML (1987) Wild bee pollinator diversity and abundance in orchard and uncultivated habitats in the Okanagan Valley, British Columbia. Can Entomol 119:735-745

Sears MK, Hellmich RL, Stanley-Horn DE, Oberhauser KS, Pleasants JM, Mattila HR, Siegfried BD, Dively GP (2001) Impact of Bt corn pollen on monarch butterfly populations: a risk assessment. PNAS 98:11937-11942

Sheperd MD, Buchmann SL, Vaughan M, Black SH (2003) Pollinator conservation handbook. Xerces Society, Portland

Shuler R, Roulston TH, Farris GE (2005) Farming practices influence wild pollinator populations on squash and pumpkin. J Econ Entomol 98:790-795

Smith JG (1969) Some effects of crop background on populations of aphids and their natural enemies on Brussels sprouts. Ann Appl Biol 63:326-330

Speight MR, Lawton JH (1976) The influence of weed cover on the mortality imposed on artificial prey by predatory ground beetles in cereal fields. Oecol 23:211-223

Steffan-Dewenter I (2002) Landscape context affects trap-nesting bees, wasps, and their natural enemies. Ecol Entomol 27:631-637

Steffan-Dewenter I, Potts SG, Packer L (2005) Pollinator diversity and crop pollination services are at risk. Trends Ecol Evol 20:651-652

Stephen WP (1955) Alfalfa pollination in Manitoba. J Econ Entomol 48:543-548

Syme PD (1975) The effects of flowers on the longevity and fecundity of two native parasites of the European pine shoot moth in Ontario. Environ Entomol 4:337-346

Telenga NA (1958) Biological method of pest control in crops and forest plants in the USSR. In: Report of the Soviet Delegation. Ninth International Conference on Quarantine and Plant Protection, Moscow, pp. 1-15

Thresh JM (1981) Pests, pathogens and vegetation: the role of weeds and wild plants in the ecology of crop pests and diseases. Pitman, Boston, MA

Ulbert L, Horst-Henning S, Klimek S (2010) Using selective herbicides to manage beneficial and rare weed species in winter wheat. J Plant Dis Prot 117:233-239

van Emden HF (1963) Observations of the effects of flowers on the activity of parasitic Hymenoptera. Entomol Mon Mag 98:265-270

van Emden HF (1965) The role of uncultivated land in the biology of crop pests and beneficial insects. Sci Hortic $17: 121-136$ 
William RD (1981) Complementary interactions between weeds, weed control practices, and pests in horticultural cropping systems. HortScience 16:508-513

Willmer P (2011) Pollination and floral ecology. Princeton University Press, Princeton

Wratten SD, van Emden HF (1995) Habitat management for enhanced activity of natural enemies of insect pests. In: Glen DM, Greaves
MP, Anderson HM (eds) Ecology and integrated farming systems. John Wiley and Sons, Chichester, pp 117-145

Wrucke MA, Arnold WE (1985) Weed species distribution as influenced by tillage and herbicides. Weed Sci 33:853-856

Zimdahl RL (1980) Weed-crop competition-a review. International Plant Protection Center, Oregon State University, Corvallis 